\title{
Photothermal Ratio Affects Plant Quality in 'Freedom' Poinsettia
}

\author{
Bin Liu' ${ }^{1}$ and Royal D. Heins ${ }^{2}$ \\ Department of Horticulture, Michigan State University, East Lansing, MI 48824-1325 \\ AdDitional INDEX wORDs. bract size, cyathia size, dry weight, Euphorbia pulcherrima, ratio of radiant to thermal energy \\ (RRT), stem strength
}

\begin{abstract}
Light (radiant energy) and temperature (thermal energy) affect quality of greenhouse crops. Radiant energy drives photosynthesis and, consequently, plant biomass accumulation. Thermal energy is the primary environmental factor driving developmental rate. The concept of a photothermal ratio (PTR), the ratio of radiant energy [moles of photosynthetic $(400$ to $700 \mathrm{~nm})$ photons $/ \mathrm{m}^{2}$ ] to thermal energy (degree-day), was proposed to describe the balance between plant growth and plant development in greenhouse crops. The objective of this study was to quantify the effect of PTR during vegetative (PTR $)$ or reproductive (PTR ${ }^{r}$ ) phases on finished plant quality of 'Freedom' poinsettia (Euphorbia pulcherrima Willd. ex Klotzsch). In Expt. 1, plants were grown under 27 combinations of three constant temperatures $\left(19,23\right.$, or $27^{\circ} \mathrm{C}$ ), three daily light integrals (DLIs) as measured by the number of photosynthetic (400 to $700 \mathrm{~nm})$ photons $\left(5,10\right.$, or $\left.20 \mathrm{~mol} \cdot \mathrm{m}^{-2} \cdot \mathrm{d}^{-1}\right)$, and three plant spacings $(15 \times 15,22 \times 22$, or $30 \times 30 \mathrm{~cm})$ from pinch to the start of short-day flower induction, and then moved to a common PTR until anthesis. In Expt. 2, plants were grown under a common PTR during the vegetative stage and then moved to combinations of three DLIs $\left(5,10\right.$, or $\left.^{15} \mathrm{~mol}^{-2} \cdot \mathrm{m}^{-2} \cdot \mathrm{d}^{-1}\right)$ and three plant spacings $(25 \times 25,30 \times 30$, or $35 \times 35 \mathrm{~cm})$ at a constant $20^{\circ} \mathrm{C}$ from the start of short days until anthesis. Both PTR $^{\mathrm{r}}$ and PTR ${ }^{\mathrm{v}}$ affected final plant dry weight (DW). All components of DW (total, stem, leaf, and bract) increased linearly as PTR ${ }^{r}$ increased, and responded quadratically to PTR $^{v}$, reaching a maximum when PTR $^{v}$ was 0.04 mol/degreeday per plant. Stem strength depended more on PTR ${ }^{\mathrm{v}}$ than PTR ${ }^{\mathrm{r}}$. When PTR ${ }^{\mathrm{v}}$ increased from 0.02 to $0.06 \mathrm{~mol} / \mathrm{degree}-$ day per plant, stem diameter increased $\approx 24 \%$, while stem strength increased $75 \%$. The size of bracts and cyathia increased linearly as PTR ${ }^{r}$ increased, but was unaffected by PTR ${ }^{\mathrm{v}}$. When PTR ${ }^{\mathrm{r}}$ increased from 0.02 to $0.06 \mathrm{~mol} / \mathrm{degree}-$ day per plant, bract area, inflorescence diameter, and cyathia diameter increased $45 \%, 23 \%$, and $44 \%$, respectively.
\end{abstract}

Production of high-quality plants is affected by radiant energy (commonly referred to as light) and temperature (thermal energy). Radiant energy [defined in this paper as number of photosynthetic (400 to $700 \mathrm{~nm}$ ) photons in units of $\mathrm{mol} \cdot \mathrm{m}^{-2} \cdot \mathrm{d}^{-1}$ ] drives photosynthesis and, consequently, plant biomass accumulation. Thermal energy is the primary environmental factor that drives developmental rate. Plants grown under high radiant energy and low thermal energy become stocky but grow and develop slowly. In contrast, plants grown under low radiant energy and high thermal energy grow and develop rapidly but become thin and weak. Horticulturists often have an intuitive awareness of these responses, and attempt to balance radiant and thermal energy to maintain desired plant quality within an economically acceptable production time. The concept of a photothermal ratio (PTR), the ratio of radiant energy to thermal energy (degree-day) in units of mol/degree-day, was proposed to quantify the balance between plant growth and development in greenhouse crops, and facilitate its regulation (Liu and Heins, 1997, 1998). Initially we expressed this concept as the ratio of radiant energy to thermal energy (RRT), but we have changed our term to photothermal ratio (PTR) to correspond with terminology used in other disciplines.

A concept similar to PTR has been applied in field crops. Nix (1976) defined photothermal quotient as a ratio of mean daily irradiation to mean temperature above a base temperature in

Received for publication 29 Dec. 1999. Accepted for publication 18 Sept. 2001 This study was funded by the American Floral Endowment. We gratefully acknowledge assistance of Tom Wallace in conducting the experiments. The cost of publishing this paper was defrayed in part by the payment of page charges. Under postal regulations, this paper therefore must be hereby marked advertisement solely to indicate this fact.

${ }^{1}$ Former graduate assistant.

${ }^{2}$ Professor. units of $\mathrm{cal} \cdot \mathrm{cm}^{-2} /$ degree-day. Islam and Morison (1992) believed that photothermal quotient was more meaningful physiologically than either temperature or irradiation, and should be considered a derived variable in regression analysis for crop yield prediction. The photothermal quotient has been used to predict seed number and yield with good results for different crops, such as wheat (Triticum aestivum L.) (Fischer, 1985; Magrin et al., 1993; Ortiz-Monasterio et al., 1994; Rawson, 1988; Savin and Slafer, 1991), rice (Oryza sativa L.) (Islam and Morison, 1992), and sunflower (Helianthus annuиs L.) (Cantagallo et al., 1997).

In contrast to field crops whose targeted yield often is the number and size of seeds or kernels, ornamental crops frequently consider whole-plant characteristics and appearance. Several workers have reported that various combinations of light level (radiant energy) and temperature (thermal energy) affected floral plant quality (Hagen, 1980; Hagen and Moe, 1981; Harris and Scott, 1968; Kaczperski et al., 1991; Kristoffersen, 1969, 1994; Merritt and Kohl, 1982; Piringer and Cathey, 1960). However, none of these authors used a ratio relating radiant and thermal energy to explain their results. In 1996, we proposed that the ratio of radiant energy to thermal energy (degree-days) might be one of the parameters controlling the quality of floral crops. Our initial studies showed that PTR was a useful parameter for predicting plant growth, development and quality (Liu and Heins, 1997, 1998).

The effects of PTR on poinsettia (Euphorbia pulcherrima) vegetative growth and development have been reported (Liu and Heins, 1997, 1998). The current work focuses on the effect of PTR on subsequent reproductive growth and development. The objective of this study was to quantify the effect of PTR during the vegetative and reproductive phases on poinsettia plant quality at anthesis. Plant quality was characterized through total plant dry weight (DW), bract and leaf area, cyathia diameter, stem diameter, and lateral-shoot strength measurements. 
Table 1. Actual average daily air temperature, daily light integral (DLI) and plant shoot-tip temperature under various light levels and plant spacings (Expt. 1). Plant temperatures were measured with a thermocouple inserted into the apex of the second lateral shoot from the top of the plant. Values are the mean of $35 \mathrm{~d}$ of the treatment \pm SE.

\begin{tabular}{|c|c|c|c|c|}
\hline \multirow{3}{*}{$\begin{array}{l}\text { Air } \\
\text { temp } \\
\left({ }^{\circ} \mathrm{C}\right)\end{array}$} & \multirow{3}{*}{$\begin{array}{c}\text { DLI } \\
\text { (daily moles } \\
\text { photons } / \mathrm{m}^{2} \text { ) }\end{array}$} & \multicolumn{3}{|c|}{ Plant shoot-tip temp $\left({ }^{\circ} \mathrm{C}\right)$} \\
\hline & & Close spacing & Medium spacing & Wide spacing \\
\hline & & $(15 \times 15 \mathrm{~cm})$ & $(22 \times 22 \mathrm{~cm})$ & $(30 \times 30 \mathrm{~cm})$ \\
\hline \multirow[t]{3}{*}{$20.0 \pm 0.2$} & $5.2 \pm 0.2$ & $19.0 \pm 0.2$ & $18.6 \pm 0.2$ & $19.2 \pm 0.2$ \\
\hline & $10.1 \pm 0.3$ & $19.5 \pm 0.2$ & $19.8 \pm 0.2$ & $19.6 \pm 0.2$ \\
\hline & $19.7 \pm 0.3$ & $21.8 \pm 0.3$ & $22.0 \pm 0.2$ & $21.4 \pm 0.2$ \\
\hline \multirow[t]{3}{*}{$23.4 \pm 0.1$} & $5.2 \pm 0.2$ & $20.6 \pm 0.2$ & $21.0 \pm 0.2$ & $21.0 \pm 0.2$ \\
\hline & $10.2 \pm 0.2$ & $21.6 \pm 0.2$ & $21.7 \pm 0.2$ & $22.1 \pm 0.2$ \\
\hline & $20.3 \pm 0.4$ & $23.7 \pm 0.2$ & $24.9 \pm 0.1$ & $25.7 \pm 0.1$ \\
\hline \multirow[t]{3}{*}{$27.0 \pm 0.1$} & $5.0 \pm 0.2$ & $25.7 \pm 0.1$ & $25.8 \pm 0.1$ & $26.0 \pm 0.1$ \\
\hline & $10.2 \pm 0.3$ & $25.3 \pm 0.2$ & $25.5 \pm 0.1$ & $25.3 \pm 0.1$ \\
\hline & $20.1 \pm 0.2$ & $25.8 \pm 0.2$ & $25.3 \pm 0.2$ & $27.3 \pm 0.1$ \\
\hline
\end{tabular}

\section{Materials and Methods}

Two experiments were conducted in four glass greenhouses in East Lansing, Mich., during Fall 1996. Rooted stem cuttings of 'Freedom' poinsettia in $15-\mathrm{cm}$-diameter (1.57-L) round pots were obtained from a commercial propagator on $23 \mathrm{Aug}$. for Expt. 1 and 29 Aug. for Expt. 2. Plants were pinched to six nodes 1 week after receipt.

EXPERIMENT 1. Plants were grown under various PTR treatments during the vegetative stage $\left(\mathrm{PTR}^{\mathrm{v}}\right)$ and a common PTR during the reproductive stage $\left(\mathrm{PTR}^{\mathrm{r}}\right)$. Immediately after pinch, plants were randomly assigned to one of 27 combinations of three constant air-temperature settings $\left(19,23\right.$, or $\left.27^{\circ} \mathrm{C}\right)$, three daily light integrals (DLIs) as measured by the number of photosynthetic $(400$ to $700 \mathrm{~nm})$ photons $\left(5,10\right.$, or $\left.20 \mathrm{~mol} \cdot \mathrm{m}^{-2} \cdot \mathrm{d}^{-1}\right)$, and three plant spacings [close $(15 \times 15 \mathrm{~cm})$, medium $(22 \times 22 \mathrm{~cm})$, or wide $(30 \times 30 \mathrm{~cm})$ ]. Plants were grown under the treatments for 5 weeks, then were moved to a glass greenhouse set to a constant 20 ${ }^{\circ} \mathrm{C}$ with natural short day (SD) $(<12 \mathrm{~h})$ and DLI conditions (average $\approx 10 \mathrm{~mol} \cdot \mathrm{m}^{-2} \cdot \mathrm{d}^{-1}$ ) for reproductive development at a common spacing of $30 \times 30 \mathrm{~cm}$.

EXPERIMENT 2. Plants were grown under a common PTR during the vegetative stage, and moved to different PTR treatments for reproductive development. Environmental conditions during vegetative growth for all plants in Expt. 2 were $23{ }^{\circ} \mathrm{C}$, a DLI of $10 \mathrm{~mol} \cdot \mathrm{m}^{-2} \cdot \mathrm{d}^{-1}$, and $22 \times 22 \mathrm{~cm}$ plant spacing. When 450 degree-days $\left(5^{\circ} \mathrm{C}\right.$ base temperature $)$ had accumulated after pinching, plants were selected randomly and assigned to one of nine combinations of three DLI $\left(5,10\right.$, or $\left.15 \mathrm{~mol} \cdot \mathrm{m}^{-2} \cdot \mathrm{d}^{-1}\right)$ and three plant spacings [close $(25 \times 25 \mathrm{~cm})$, medium $(30 \times 30 \mathrm{~cm})$, or wide $(35 \times 35 \mathrm{~cm})]$ at $20^{\circ} \mathrm{C}$ under natural short-day conditions $(<12 \mathrm{~h})$. Plant spacings were greater in Expt. 2 than in Expt. 1 because plants were larger at the onset of PTR ${ }^{\mathrm{r}}$ treatments, having completed $25 \mathrm{~d}$ of vegetative growth. Daily duration of the supplemental lighting was always $<11.5 \mathrm{~h}$. The experiment was terminated at anthesis.

Expt. 1 was a split-split plot design with temperature as the main plot, DLI as the split plot, and plant spacing as the split-splitplot. A split-plot design was used in Expt. 2 with DLI the main plot, and plant spacing the split plot. There were five plants in each treatment. Guard rows consisting of plants at comparable spacing surrounded the treatment plants to avoid edge effects.

Photosynthetic photon flux $(P P F)$ was measured at the top and bottom of the plant canopy with line quantum sensors constructed of 18 G2711 photodiodes (Hamamatsu, Japan) on 1-m bars, connected to dataloggers (CR10; Campbell Scientific, Logan, Utah). Intercepted light was calculated by subtracting light transmitted to the bottom of the canopy from incident light on the top of the canopy. Various DLI levels were obtained through internal greenhouse shading (sunny days) with 50\% shading screens (LS 15F; Ludvig Svensson, Kinna, Sweden) or by supplemental lighting (cloudy days) of $\approx 200,200,80$, or $40 \mathrm{mmol} \cdot \mathrm{m}^{-2} \cdot \mathrm{s}^{-1} P P F$ for the $20,15,10$, or $5 \mathrm{~mol} \cdot \mathrm{m}^{-2} \cdot \mathrm{d}^{-1}$ treatments, respectively, from high-pressure sodium lamps. Expected DLI was estimated each morning at $0800 \mathrm{HR}$ based on the weather forecast, and screens or lamps were actuated as necessary based on the prediction. Dataloggers were programmed to calculate DLI as it accumulated throughout the day. Actual DLI was reviewed at 1400 HR daily, and shading screens or lamps were readjusted at that time. Actual DLI was reviewed again at $1700 \mathrm{HR}$ daily, and if further supplemental lighting was needed, the necessary duration was calculated manually and entered into the computer controlling the lamps. The desired DLI was adjusted up or down each day to compensate for any deviations from the target DLI of the previous day. Maximum variation in DLI was $<0.5 \mathrm{~mol} \cdot \mathrm{m}^{-2} \cdot \mathrm{d}^{-1}$.

Greenhouse air temperature was controlled by a climatecontrol computer (model CD750; Priva, De Lier, Holland). Shoot-tip temperature was measured by inserting a 36-gauge $(0.127-\mathrm{mm})$ thermocouple into the apex of the second lateral shoot from the top of the plant, and moving the thermocouple up as the plant grew. Actual air temperatures and plant shoot-tip temperatures (Table 1) were recorded by the datalogger which collected temperature data every $10 \mathrm{~s}$ and recorded the hourly average. Because plant temperature rather than air temperature plays an important role in control of plant developmental rate (Harris and Scott, 1968; Ritchie and NeSmith, 1991; Watts, 1972), all analyses were based on the actual plant temperatures.

DW data (total, stem, and leaf; dried at $70{ }^{\circ} \mathrm{C}$ for $5 \mathrm{~d}$ ) were collected on five plants from each treatment at the start of short days (SDs). At anthesis, plant height and DW [total, stem, bract, and green leaves (including transitional leaves)] were measured, and total leaf and bract areas were determined (Delta-T Devices, Cambridge, England). Stem strength of six lateral shoots was measured by using a force-gauge meter (Hunter Spring Co., Lansdale, Pa.). The meter was positioned at the lowest node of each lateral shoot, and the meter reading was recorded when the shoot was broken from the main stem by using the meter to push downward. Larger force-gauge readings indicated stronger stems. Additional measurements were made on the second lateral shoot from the top of the plant including shoot and internode length and 
Table 2. The coefficient of determination $\left(r^{2}\right)$ of the linear regression between the ratio of radiant energy [moles of photosynthetic (400 to $\left.700 \mathrm{~nm}\right)$ photons $/ \mathrm{m}^{2}$ ] to thermal energy (degree-day) termed photothermal ratio (PTR) plants received during the vegetative (PTR $\left.{ }^{\mathrm{v}}\right)$ or reproductive stage $\left(\mathrm{PTR}^{\mathrm{r}}\right)$, and plant characteristics at anthesis. Measured PTR was further refined into three expressions; i.e., $\mathrm{PTR}_{\text {area }},\left(\mathrm{mol}^{\circ} \mathrm{m}^{-2}\right.$ per degree-day) was the amount of incident light on a unit area, PTR $_{\text {plant }}$ was the amount of light available for a plant (mol/degree-day per plant), and PTR intercept was the amount of light intercepted by a plant (mol/degree-day per plant). Lateral shoots were numbered from the top of the plant.

\begin{tabular}{|c|c|c|c|c|c|c|c|}
\hline \multirow[b]{2}{*}{ Parameter } & \multirow{2}{*}{$\begin{array}{c}\text { Lateral } \\
\text { shoot }\end{array}$} & \multicolumn{3}{|c|}{$\mathrm{PTR}^{\mathrm{v}}$ (Expt. 1) } & \multicolumn{3}{|c|}{$\mathrm{PTR}^{\mathrm{r}}$ (Expt. 2) } \\
\hline & & PTR $_{\text {area }}$ & PTR $_{\text {plant }}$ & PTR $_{\text {intercept }}$ & $\mathrm{PTR}_{\text {area }}$ & PTR $_{\text {plant }}$ & PTR $_{\text {intercept }}$ \\
\hline Total DW & --- & $0.35^{* *}$ & $0.46^{* * * *}$ & $0.59^{* * * *}$ & $0.61^{*}$ & $0.94^{* * * *}$ & $0.94^{* * * *}$ \\
\hline Stem DW & --- & $0.29^{* *}$ & $0.29^{* *}$ & $0.41^{* * * *}$ & $0.78^{* *}$ & $0.82^{* * * *}$ & $0.89^{* * * *}$ \\
\hline Green-leaf DW & --- & $0.35^{* *}$ & $0.52^{* * * *}$ & $0.63^{* * *}$ & $0.56^{* *}$ & $0.94^{* * * *}$ & $0.93^{* * * *}$ \\
\hline Bract DW & --- & $0.31^{* * *}$ & $0.39^{* * * *}$ & $0.47^{* * * *}$ & $0.55^{*}$ & $0.95^{* * * *}$ & $0.93^{* * * *}$ \\
\hline \multicolumn{8}{|l|}{ Stem diameter } \\
\hline \multirow[t]{7}{*}{ Lateral shoot breakage force } & $2^{\text {nd }}$ & $0.39^{* * * *}$ & $0.48^{* * * *}$ & $0.59^{* * * *}$ & $0.59^{*}$ & $0.77^{* *}$ & $0.75^{* *}$ \\
\hline & $1^{\mathrm{st}}$ & $0.19^{*}$ & $0.10^{\mathrm{NS}}$ & $0.16^{*}$ & $0.04^{\mathrm{NS}}$ & $0.07^{\mathrm{NS}}$ & $0.02^{\mathrm{NS}}$ \\
\hline & $2^{\text {nd }}$ & $0.10^{\mathrm{NS}}$ & $0.09^{\mathrm{NS}}$ & $0.13^{\mathrm{Ns}}$ & $0.00^{\mathrm{NS}}$ & $0.15^{\mathrm{NS}}$ & $0.11^{\mathrm{NS}}$ \\
\hline & $3^{\text {rd }}$ & $0.03^{\mathrm{NS}}$ & $0.13^{\mathrm{NS}}$ & $0.14^{\mathrm{Ns}}$ & $0.23^{\mathrm{NS}}$ & $0.19^{\mathrm{NS}}$ & $0.23^{\mathrm{Ns}}$ \\
\hline & $4^{\text {th }}$ & $0.09^{\mathrm{NS}}$ & $0.15^{*}$ & $0.18^{*}$ & $0.00^{\mathrm{NS}}$ & $0.06^{\mathrm{NS}}$ & $0.03^{\mathrm{NS}}$ \\
\hline & $5^{\text {th }}$ & $0.01^{\mathrm{NS}}$ & $0.24^{* *}$ & $0.28^{* *}$ & $0.05^{\mathrm{NS}}$ & $0.06^{\mathrm{NS}}$ & $0.05^{\mathrm{NS}}$ \\
\hline & $6^{\text {th }}$ & $0.20^{*}$ & $0.66^{* * * *}$ & $0.63^{* * * *}$ & $0.19^{\mathrm{NS}}$ & $0.04^{\mathrm{NS}}$ & $0.05^{\mathrm{NS}}$ \\
\hline Cyathia diameter & $2^{\text {nd }}$ & $0.07^{\mathrm{NS}}$ & $0.05^{\mathrm{NS}}$ & $0.08^{\mathrm{NS}}$ & $0.50^{*}$ & $0.90^{* * * *}$ & $0.82^{* * * *}$ \\
\hline Inflorescence diameter & $2^{\text {nd }}$ & $0.09^{\mathrm{NS}}$ & $0.08^{\mathrm{NS}}$ & $0.15^{*}$ & $0.66^{* *}$ & $0.78^{* *}$ & $0.82^{* * * *}$ \\
\hline Bract area & --- & --- & --- & --- & $0.64^{* *}$ & $0.95^{* * * *}$ & $0.94^{* * * *}$ \\
\hline Plant height & --- & $0.11^{\mathrm{Ns}}$ & $0.10^{\mathrm{NS}}$ & $0.16^{*}$ & $0.06^{\mathrm{NS}}$ & $0.02^{\mathrm{NS}}$ & $0.02^{\mathrm{NS}}$ \\
\hline Lateral shoot length & $2^{\text {nd }}$ & $0.05^{\mathrm{NS}}$ & $0.04^{\mathrm{NS}}$ & $0.08^{\mathrm{NS}}$ & $0.07^{\mathrm{NS}}$ & $0.33^{\mathrm{NS}}$ & $0.29^{\mathrm{NS}}$ \\
\hline Internode length & $2^{\text {nd }}$ & $0.00^{\mathrm{NS}}$ & $0.07^{\mathrm{NS}}$ & $0.03^{\mathrm{NS}}$ & $0.04^{\mathrm{NS}}$ & $0.26^{\mathrm{NS}}$ & $0.17^{\mathrm{NS}}$ \\
\hline Plant diameter & --- & $0.00^{\mathrm{NS}}$ & $0.00^{\mathrm{NS}}$ & $0.00^{\mathrm{NS}}$ & $0.05^{\mathrm{NS}}$ & $0.06^{\mathrm{NS}}$ & $0.05^{\mathrm{NS}}$ \\
\hline
\end{tabular}

$\overline{\mathrm{Ns}, *, * *, * * * *}$ Nonsignificant or significant at $P=0.05,0.01$, or 0.001 , respectively.

average diameter of the first three basal internodes. Cyathia and inflorescence diameter of the second lateral shoot were determined by measuring the widest and narrowest diameters of each, then recording the mean. Bracts were defined as leaves with $>80 \%$ red color, and transitional leaves were colored leaves positioned between the green leaves and the bracts. DW gain during the reproductive stage $\left(\mathrm{DW}_{\text {rep }}\right)$ was calculated by subtracting average DW at the start of SDs from final DW.

Measured PTR was further refined into three expressions; i.e., $\mathrm{PTR}_{\text {area }}, \mathrm{PTR}_{\text {plant }}$, and $\mathrm{PTR}_{\text {intercept }}$ (Liu and Heins, 1998). The PTR $_{\text {area }}$ (moles of photosynthetic (400 to $700 \mathrm{~nm}$ ) photons $/ \mathrm{m}^{2}$ per degree-day) was the amount of incident light on a unit area, PTR $_{\text {plant }}$ was the amount of light available for a plant (moles of photosynthetic (400 to $700 \mathrm{~nm}$ ) photons/degree-day per plant), and PTR $_{\text {intercept }}$ was the amount of light intercepted by a plant (moles of photosynthetic (400 to $700 \mathrm{~nm}$ ) photons/degree-day per plant).

Regression and general linear models were fitted using the Statistical Analysis Systems Institute (SAS) PROC GLM routine (SAS Inst., Inc., Cary, N. C.). The least square principle was applied to fit the general linear models.

\section{Results}

The relationships between the three expressions of PTR (i.e., $\mathrm{PTR}_{\text {area }}, \mathrm{PTR}_{\text {plant }}$, or PTR $\left.\mathrm{P}_{\text {intercept }}\right)$ and plant characteristics measured in the two experiments were analyzed using linear regression (Table 2). Among the three expressions of PTR, PTR intercept $_{\text {. }}$ correlated more closely with the data than $\mathrm{PTR}_{\text {plant }}$ or $\mathrm{PTR}_{\text {area }}$. Therefore, $\mathrm{PTR}_{\text {intercept }}$ Was chosen as an independent variable in the following analysis.

The PTR ${ }_{\text {intercept }}$ and PTR $_{\text {intercept }}^{r}$ had different effects on final plant DW (Fig. 1). In Expt. 1, DW at the end of SDs increased linearly as PTR ${ }_{\text {intercept }}$ increased (Fig. 1A-D, open circles). All final DW components responded to $\mathrm{PTR}^{\mathrm{v}}{ }_{\text {intercept }}$ quadratically (Fig. 1A-D, solid symbols). Final plant DW increased as PTR ${ }_{\text {intercept }}$ increased up to $\approx 0.04 \mathrm{~mol} /$ degree-day per plant, but further increases in PTR ${ }_{\text {intercept }}$ did not improve final plant DW accumulation.

In Expt. 2, all components of DW increased linearly as PTR $_{\text {intercept }}$ increased (Fig. 1E-H, solid symbols). The slope of the linear regressions in Fig. 1E-H can be interpreted as the rate of DW increase per mole of photons for each degree-day. Of the different organs, bract DW increased at the greatest rate: $63 \mathrm{~g}$ per mol/degree-day per plant (Fig. $1 \mathrm{H})$. Stem and green leaf DW increased at 22 and $50 \mathrm{~g}$ per mol/degree-day per plant (Fig. 1F$\mathrm{G})$, respectively.

Analysis of the relationship between $\mathrm{PTR}^{\mathrm{v}}{ }_{\text {intercept }}$ and final plant DW in Expt. 1 is complicated by the fact that plants were under different conditions before and after the start of SDs. At the onset of SDs, plants had accumulated different DW (total, stem, and leaf) following growth under different PTR ${ }^{\mathrm{v}}$ treatments for 5 weeks (Fig. 1A-C, open symbols). The net gain in plant DW during the subsequent SD flowering period was plotted against $\mathrm{PTR}_{\text {intercept }}$ and the relationships showed a quadratic relationship within each temperature regime (Fig. 2A-C). The aftereffect of $\mathrm{PTR}_{\text {intercept }}$ on net plant DW gain during reproductive development was obvious. The most DW net gain during reproductive development was achieved when $\mathrm{PTR}^{\mathrm{v}}{ }_{\text {intercept }}$ was $\approx 0.050 \mathrm{~mol} /$ degree-day per plant at $19{ }^{\circ} \mathrm{C}, 0.055$ at $23^{\circ} \mathrm{C}$, and 0.035 at $27^{\circ} \mathrm{C}$. In Expt. 2, net DW gain during reproductive development (Fig. 2D-F) increased linearly as PTR $\mathrm{r}_{\text {intercept }}$ increased, as did total DW gain (Fig. 1E-G).

Both vegetative and reproductive $\mathrm{PTR}_{\text {intercept }}$ were correlated 
positively with stem diameter at anthesis (Fig. 3A and C, solid symbols). However, the $\mathrm{PTR}^{\mathrm{v}}{ }_{\text {intercept }}$ had a significantly greater effect on stem diameter than the PTR ${ }_{\text {intercept }}$. The slope of the linear regressions in Fig. 3A and $\mathrm{C}$ represents the rate of stem diameter increase per mole of photons for each degree-day, and the rate was about twice as great with a PTR ${ }^{v}{ }_{\text {intercept }}$ increase as with a PTR ${ }_{\text {intercept }}$ increase (32.8 vs. $17.0 \mathrm{~mm}$ per mol/degree-day). An increase in $\mathrm{PTR}_{\text {intercept }}$ from 0.02 to $0.06 \mathrm{~mol} /$ degree-day per plant during vegetative development (Expt. 1) resulted in an increase in stem diameter of $\approx 1.3 \mathrm{~mm}$, but a similar increase during reproductive development (Expt. 2) resulted in an increase of only $0.7 \mathrm{~mm}$.

Fig. 1. Effects of the ratio of radiant energy [moles of photosynthetic (400 to 700 $\mathrm{nm}$ ) photons $/ \mathrm{m}^{2}$ ] to thermal energy (degree-day) termed photothermal ratio (PTR) intercepted by poinsettia plants during the vegetative stage ( $\mathrm{PTR}^{v_{\text {intercept }}}$ or the reproductive stage $\left(\mathrm{PTR}_{\text {intercept }}^{\mathrm{r}}\right)$ on plant dry weight $(\mathrm{DW})$ accumulation at the onset of short-day induction (open symbols) and at anthesis (solid symbols). ${ }^{* * *}$ Significant at $P=0.001$.
The PTR ${ }^{v}$ intercept had more influence on stem strength than the PTR $_{\text {intercept }}^{r}$ (Table 2). Generally, the basal lateral shoots were more sensitive to PTR than apical shoots. There was a significant linear relationship between stem strength on the sixth (basal) lateral shoot and PTR ${ }_{\text {intercept }}$ (Fig. 3B) but not PTR ${ }_{\text {intercept }}$ (Fig. 3D). When PTR ${ }_{\text {intercept }}$ increased from 0.02 to $0.06 \mathrm{~mol} /$ degree-day per plant, the breakage force increased from 310 to $547 \mathrm{~g}$, a $75 \%$ increase in stem strength.

Inflorescence and cyathia diameter were affected by $\mathrm{PTR}_{\text {intercept, }}^{\mathrm{r}}$, not PTR ${ }_{\text {intercept }}$ (Fig. 4). Plants developed larger bracts and cyathia as PTR ${ }_{\text {intercept }}^{r}$ increased. Plants grown under a PTR ${ }_{\text {intercept }}^{\mathrm{r}}$ of 0.09 $\mathrm{mol} /$ degree-day per plant produced a $39-\mathrm{cm}$-diameter inflorescence and 17 -mm-diameter cyathia. These diameters were $\approx 10$ $\mathrm{cm}$ and $8 \mathrm{~mm}$ larger, respectively, than those for plants grown at a PTR ${ }_{\text {intercept }}^{\mathrm{r}}$ of $0.02 \mathrm{~mol} /$ degree-day per plant. There was a similar tendency in total bract area (Fig. 5), which was $0.32 \mathrm{~m}^{2}$ in the highest PTR ${ }_{\text {intercept }}^{\mathrm{r}}$ treatment and $0.16 \mathrm{~m}^{2}$ in the lowest PTR ${ }_{\text {intercept }}^{\mathrm{r}}$ treatment. Plant diameter, lateral shoot and internode length, and plant height were not affected by either PTR ${ }^{\mathrm{v}}$ or PTR ${ }^{\mathrm{r}}$ (Table 2).

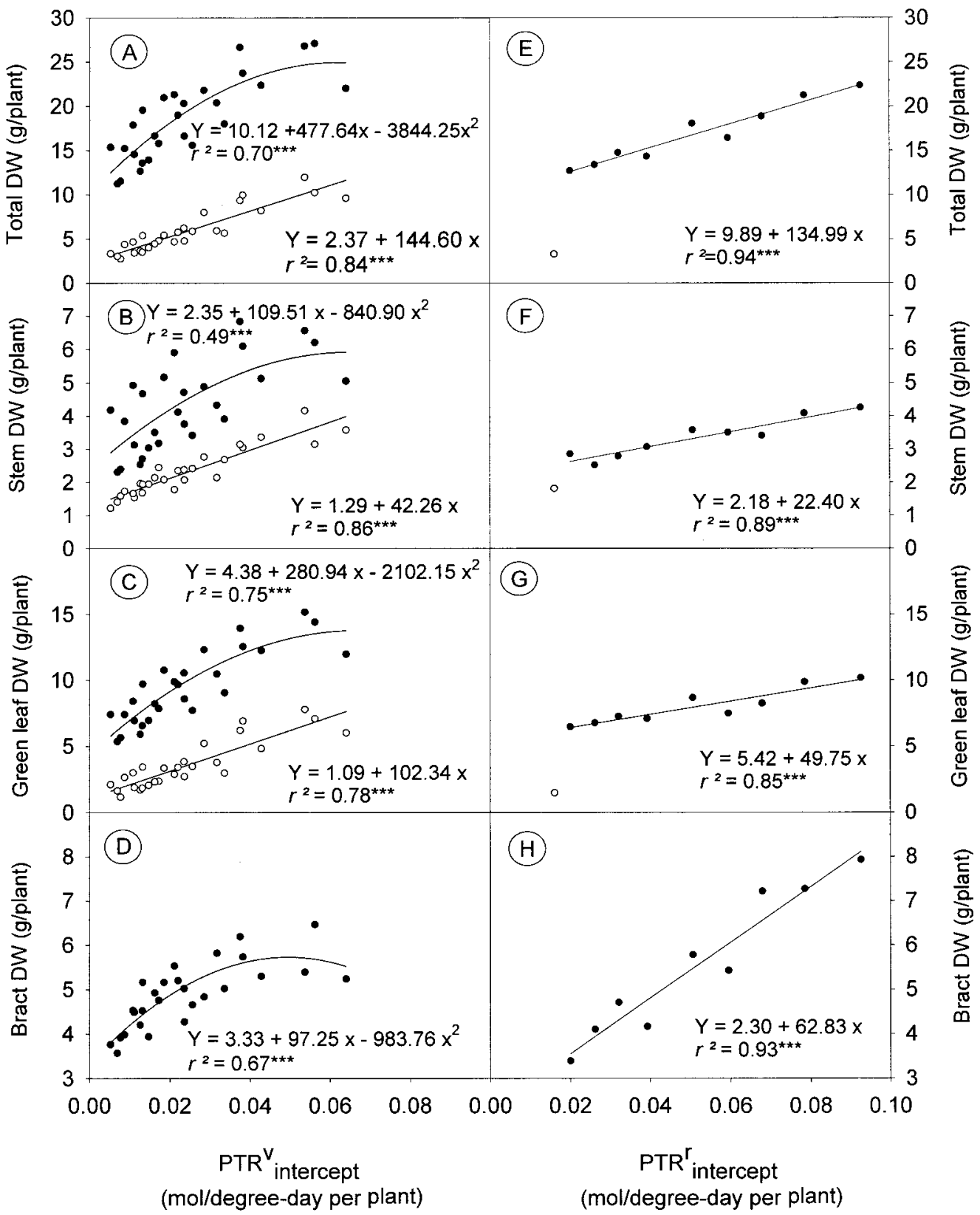

\section{Discussion}

The PTR concept describes light energy available for photosynthesis per growing degreeday. Since plant developmental rate is a linear function of temperature, i.e., number of degreedays above the base temperature, then PTR also describes light energy available for photosynthesis per fraction of plant development, e.g., unfolding of one leaf, development of a flower, etc. Plant photosynthesis and drymatter accumulation increase as intercepted light increases, while plant developmental rate increases as temperature increases from the base to the optimum temperature. Plant biomass accumulation per fraction of plant development, therefore, depends on PTR. A large PTR intercept $_{\text {means }}$ that plants intercept more photons, thus accumulating more biomass, during the current fraction of development. This relationship has been quantified in our previous (Liu and Heins, 1997, 1998) and present experiments (e.g., Fig. 1A-C, open symbols; Fig. 1E-H, solid symbols).

The three expressions of PTR can be used in different situations. The PTR area, $_{\text {, which is based }}$ on the number of incident photosynthetic photons per unit area, can be used most appropriately when plants are widely spaced 
and are not shading each other, and the amount of light available for each plant depends only on irradiance. When the plant canopy overlaps and becomes solid, light available for each plant depends on irradiance and plant spacing. In this situation, $\mathrm{PTR}_{\text {plant }}$, which is based on the number of photosynthetic photons available per plant, is more appropriate than PTR area. The PTR $_{\text {intercept is a }}$ better expression than the other two because it is related directly to the number of photosynthetic photons intercepted by a plant. However, because light interception is a dynamic factor dependent on leaf area, it is more difficult to calculate than PTR $_{\text {area }}$ or PTR $_{\text {plant. }}$.

Further examination of the effect of PTR on total DW accumulation before (Fig. 1A, open symbols) or after (Fig. 1E, solid symbols) the onset of SDs showed that total DW increased at a similar rate in both situations (between 145 and $135 \mathrm{~g}$ per mol/ degree-day per plant). The slightly lower rate during reproductive development may be due to shading of leaves by developing

Fig. 2. Effects of the ratio of radiant energy [moles of photosynthetic (400 to 700 $\mathrm{nm}$ ) photons $/ \mathrm{m}^{2}$ ] to thermal energy (degree-day) termed photothermal ratio (PTR) intercepted by plants during the vegetative stage $\left(\mathrm{PTR}^{\mathrm{v}}{ }_{\text {intercept }}\right.$ or the reproductive stage $\left(\mathrm{PTR}^{\mathrm{r}}{ }_{\text {intercept }}\right)$ on plant dry weight $(\mathrm{DW})$ accumulation during the reproductive stage $\left(\mathrm{DW}_{\text {rep }}\right)$. In $\mathrm{A}, \mathrm{B}$, and $\mathrm{C}$, nonlinear regressions were fitted to the three different temperatures $\left(19{ }^{\circ} \mathrm{C}, \square 23{ }^{\circ} \mathrm{C}\right.$, and $\boldsymbol{\nabla} 27{ }^{\circ} \mathrm{C}$ ). ns, ${ }^{*}, * *, * * * *$ Nonsignificant or significant at $P=0.05,0.01$, or 0.001 , respectively. bracts, although no data were collected to quantify this shading, which always occurs during poinsettia reproductive development. However, stem growth was more closely related to the $\mathrm{PTR}^{\mathrm{v}}$. The rate of increase in stem DW during vegetative development was about twice that of the increase during reproductive development (42 vs. $22 \mathrm{~g}$ per mol/degree-day). Similarly, the rate of increase in stem diameter was greater during the vegetative stage than during the reproductive stage (42 vs. $17 \mathrm{~mm}$ per mol/ degree-day, respectively; Fig. 3A, open symbols, and 3C). Moreover, the increased stem diameter at the start of short days was still present at anthesis (Fig. 3A, solid symbols). The final stem diameter of the second lateral shoot from the top increased $\approx 24 \%$ as PTR ${ }^{\mathrm{v}}$ increased from 0.02 to $0.06 \mathrm{~mol} /$ degree-day per plant, an increase in stem cross-sectional area of $\approx 50 \%$.

It is clear that $\mathrm{PTR}^{\mathrm{r}}$ affected bract DW accumulation more than that of other organs (Fig. 1F-H). After flower induction, assimilate partitioning patterns change. The reproductive sink becomes strong, which may limit the assimilate partitioning to leaf, stem, and root growth (Gardner et al., 1985). Bracts are part of the reproductive organs in poinsettia, and their DW increased faster than that of other organs as PTR ${ }^{\mathrm{r}}$ increased (i.e., 63, 50, and 22 $\mathrm{g} \cdot \mathrm{mol}^{-1}$ per degree-day per plant for bracts, green leaves, and stems, respectively).

The effect of PTR ${ }^{v}$ on DW gain can persist to anthesis (Fig. 2). The aftereffect of $\mathrm{PTR}^{\mathrm{v}}$ on DW varied with temperature during the vegetative stage because plants grown at higher temperatures developed more leaf area than those at lower temperatures. Therefore, even though plants were under the same environmental and spacing conditions during the reproductive stage, those with a large initial leaf area intercepted more light and accumulated more biomass than those with a smaller initial leaf area.

Lateral stem breakage is problematic in poinsettia production, since stem breakage reduces plant marketability and economic value. Many factors, including genetics, mineral nutrition, and cultural practices, may cause lateral stem breakage (Leonard and Nell, 1998). We found that PTR was one of the factors that affect basal stem breakage (Table 2; Fig. 3B). The higher the PTR ${ }^{v}$, the stronger the lowest lateral shoot. In contrast, PTR ${ }^{\mathrm{r}}$ had little or no effect on stem breakage, probably because the lateral shoots were well developed before flower induction. Another important 


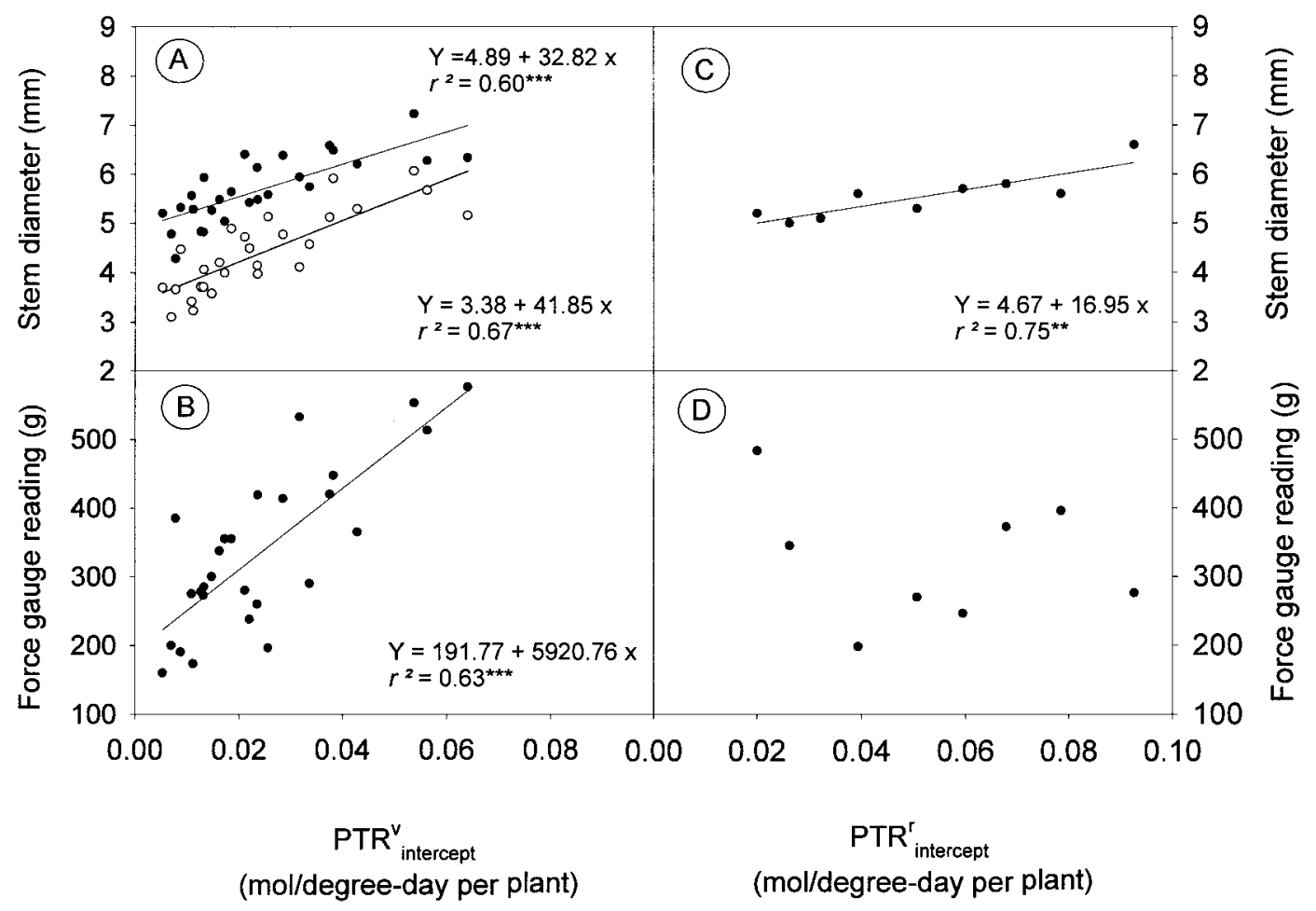

Fig. 3. Effects of the ratio of radiant energy [moles of photosynthetic (400 to $700 \mathrm{~nm}$ ) photons $/ \mathrm{m}^{2}$ ] to thermal energy (degree-day) termed photothermal ratio (PTR) intercepted by plants during the vegetative stage $\left(\mathrm{PTR}^{\mathrm{v}} \mathrm{intercept)}_{\text {) }}\right.$ or the reproductive stage $\left(\mathrm{PTR}_{\text {intercept }}\right)$ on stem diameter of the second lateral shoot from the top of the plant, and stem strength of the sixth lateral (basal) shoot at anthesis (solid symbols) and at the onset of flowerinduction (open symbols). ${ }^{* *, * * *}$ Significant at $P=$ 0.01 or 0.001 , respectively.

Although a higher PTR $_{\text {intercept }}$ did not reduce stem breakage, a higher $\mathrm{PTR}_{\text {intercept }} \mathrm{r}_{\text {improved the }}$ finished plant quality by increasing bract and cyathia size. Bract area, inflorescence diameter, and cyathia diameter increased linearly as PTR ${ }_{\text {intercept increased }}$ (Fig. 4C and D, Fig. 5). When PTR ${ }_{\text {intercept }}$ increased

reason is that PTR ${ }^{\mathrm{v}}$ profoundly affected stem growth and development. Stem DW accumulation increased significantly as the PTR $^{v}$ increased, resulting in thicker and stronger stems. Recently, Leonard and Nell (1998) reported that stem diameter at planting was one of the major factors that influenced stem breakage. Thinner cuttings $(<4.5 \mathrm{~mm}$ in diameter) had twice as much breakage as thicker cuttings $(>7.5 \mathrm{~mm}$ in diameter). Since plants grown under a high PTR $^{\mathrm{v}}$ would develop thick stems, the effect of PTR on stem breakage might start as early as the stock-plant stage.

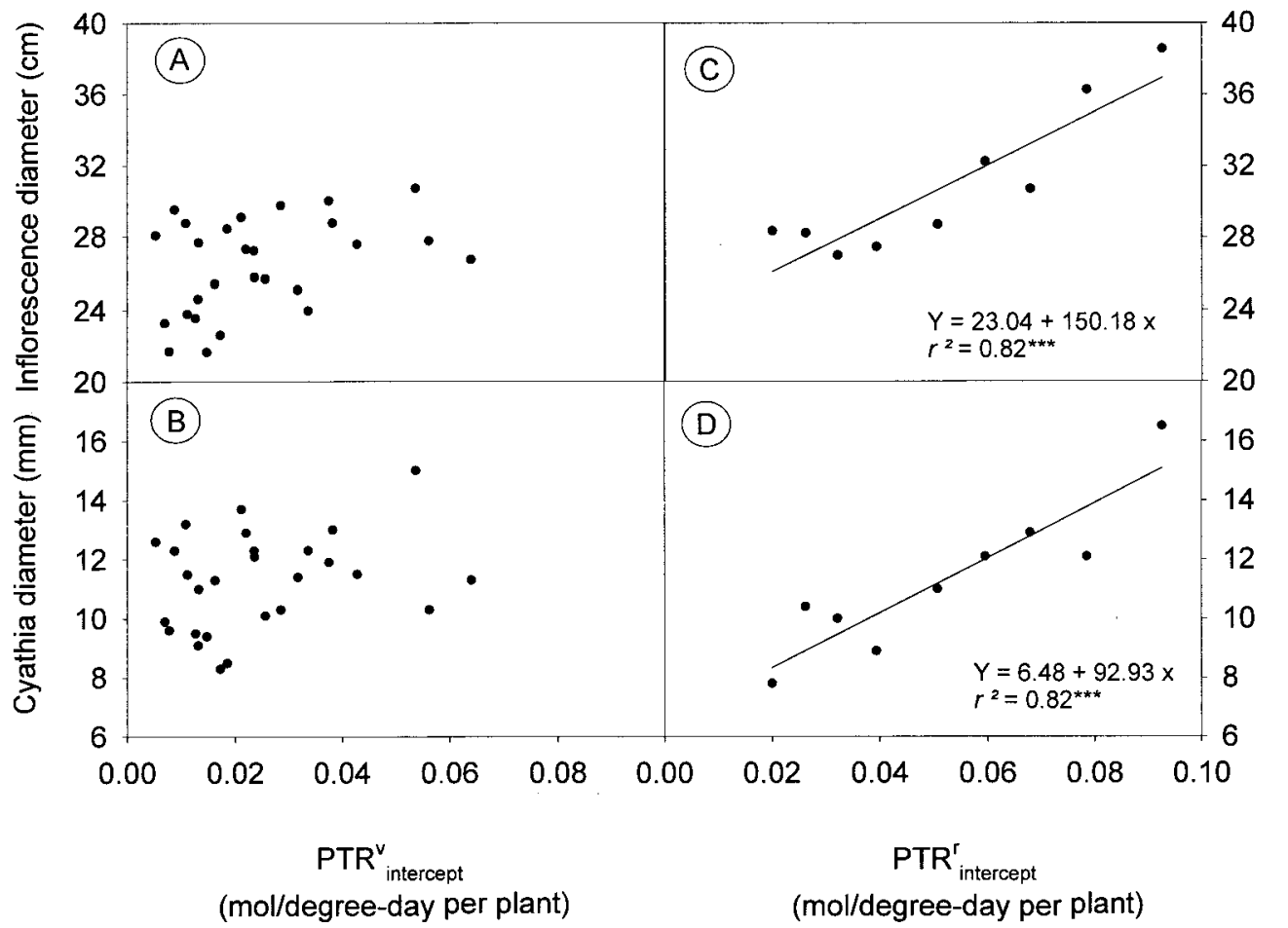

from 0.02 to $0.06 \mathrm{~mol} /$ degree-day per plant, bract area, inflorescence diameter, and cyathia diameter increased $\approx 45 \%, 23 \%$, and $44 \%$, respectively. Greater DW accumulation in the higher PTR ${ }^{\mathrm{r}}$ may not be the only reason for the larger bract size. According to Hall (1992), bract size increases linearly as average temperature increases from 15 to $24{ }^{\circ} \mathrm{C}$. In our experiment, average plant shoot-tip temperature was $\approx 1{ }^{\circ} \mathrm{C}$ higher under the high DLI treatment $\left(15 \mathrm{~mol} \cdot \mathrm{m}^{-2} \cdot \mathrm{d}^{-1}\right)$ than the low DLI treatment $\left(5 \mathrm{~mol} \cdot \mathrm{m}^{-2} \cdot \mathrm{d}^{-1}\right)$. Temperature differences would occur during the day when supplemental lights (high-pressure sodium lamps) were turned on in the high DLI treatment. The larger bracts may result from both high PTR and higher day temperature.

Cyathia abscission is another parameter related to poinsettia plant quality. Increasing temperature, reducing irradiance by shading, or using closer spacing promoted cyathia abscission (Miller and Heins, 1986). Therefore, itcan be inferred that cyathia abscission also is related to PTR.

Fig. 4. Effects of the ratio of radiant energy [moles of photosynthetic (400 to $700 \mathrm{~nm}$ ) photons $/ \mathrm{m}^{2}$ ] to thermal energy (degree-day) termed photothermal ratio (PTR) intercepted by plants during the vegetative stage $\left(\mathrm{PTR}_{\text {intercept }}^{\mathrm{v}}\right.$ or the reproductive stage $\left(\mathrm{PTR}_{\text {intercept }}^{\mathrm{r}}\right)$ on inflorescence and cyathia diameter of the second lateral shoot from the top of the plant at anthesis. *** Significant at $P=0.001$. 


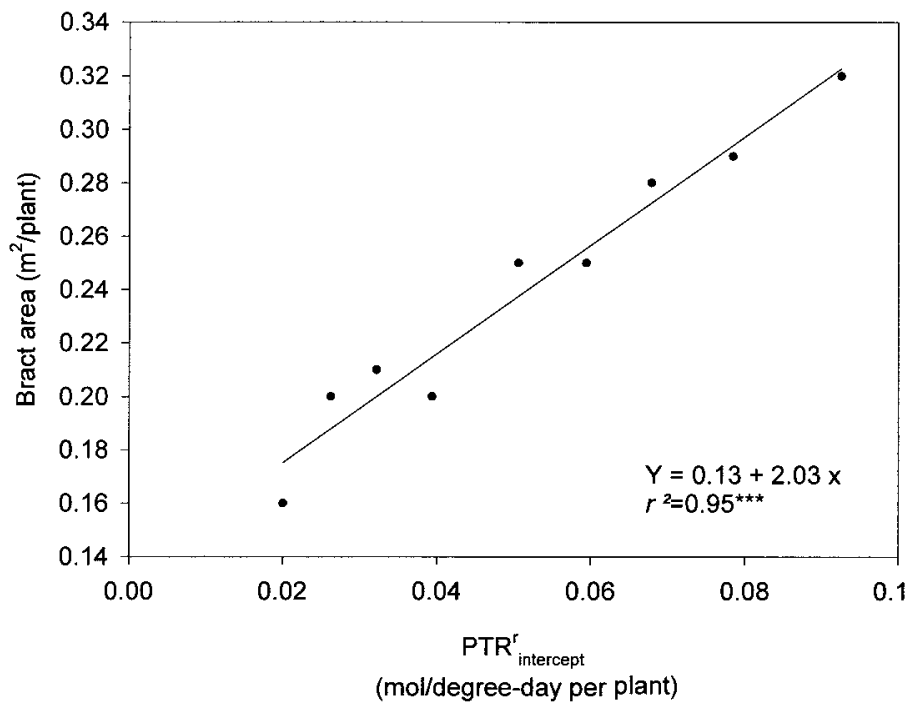

Fig. 5. Effects of the ratio of radiant energy [moles of photosynthetic (400 to 700 $\mathrm{nm}$ ) photons $/ \mathrm{m}^{2}$ ] to thermal energy (degree-day) termed photothermal ratio (PTR) intercepted by plants during the reproductive stage $\left(\mathrm{PTR}_{\text {intercept }}\right.$ ) on bract area at anthesis. ${ }^{* * *}$ Significant at $P=0.001$.

Increasing PTR near anthesis by reducing temperature or increasing DLI may reduce cyathia abscission.

Results presented herein further confirm that poinsettia plant quality is related to the photothermal ratio (PTR). A high PTR during the vegetative stage will enhance plant stem strength, perhaps reducing stem breakage at anthesis. During the reproductive stage, a high PTR improves plant appearance by increasing bract area and cyathia diameter and, possibly, reducing cyathia abscission.

\section{Literature Cited}

Cantagallo, J.E., C.A. Chimenti, and A.J. Hall. 1997. Number of seeds per unit area in sunflower correlates well with a photothermal quotient. Crop Sci. 37:1780-1786.

Fischer, R.A. 1985. Number of kernels in wheat crops and the influence of solar radiation and temperature. J. Agr. Sci. (Cambridge) 105:447-461.

Gardner, F.P., R.B. Pearce, and R.L. Mitchell. 1985. Physiology of crop plants. Iowa State Univ. Press, Ames.

Hagen, P. 1980. Effects of plant distances the first three weeks after potting on growth in potted poinsettia plant. Gartneryrket 70:758-760.

Hagen,P. and R. Moe. 1981.Effect of temperature and light on lateral branching in poinsettia (Euphorbia pulcherrima Willd.). Acta Hort. 128:47-51.

Hall, J. 1992. The effect of temperature on poinsettias. The poinsettia 4:13-16.
Harris, G.P. and M.A. Scott. 1968. Studies on the glasshouse carnation: Effects of light and temperature on the growth and development of the flower. Ann. Bot. 33:143-152.

Islam, M.S. and J.I.L. Morison. 1992. Influence of solar radiation and temperature on irrigated rice grain in Bangladesh. Field Crops Res. 30:13-28.

Kaczperski, M.P., W.H. Carlson, and M.G. Karlsson. 1991. Growth and development of Petunia $\times$ hybrida as a function of temperature and irradiance. J. Amer. Soc. Hort. Sci. 116:232-237.

Kristoffersen, T. 1969. Influence of daylength and temperature on growth and development in poinsettia (Euphorbia pulcherrima Willd.). Acta Hort. 14:73-89.

Kristoffersen, T. 1994. Early Norwegian studies of growth and development in poinsettia, p. 15-21. In: E. Stromme (ed.). The scientific basis of poinsettia production. Agr. Univ. Norway, N-1432 Aas.

Leonard, R.T. and T.A. Nell. 1998. The key to postproduction performance of poinsettias. Ohio Florists Assn. Bul. 825:3-6.

Liu, B. and R.D. Heins. 1997. Is plant quality related to the ratio of radiant energy to thermal energy? Acta Hort. 435:171-182.

Liu, B. and R.D. Heins. 1998. Modeling poinsettia vegetative growth and development: The response to the ratio of radiant to thermal energy. Acta Hort. 456:133-142.

Magrin, G.O., A.J. Hall, C. Baldy, and M.O. Grondona. 1993. Spatial and interannual variations in the photothermal quotient: Implications for the potential kernel number of wheat crops in Argentina. Agr. For. Meteorol. 67:29-41.

Merritt, R.H. and J.C. Kohl, Jr. 1982. Effect of root temperature and photoperiod on growth and crop productivity efficiency of petunia. $\mathrm{J}$. Amer. Soc. Hort. Sci. 107:997-1000.

Miller, S.H. and R.D. Heins. 1986. Factors influencing premature cyathia abscission in poinsettia 'Annette Hegg Dark Red'. J. Amer. Soc. Hort. Sci. 111:114-121.

Nix, H.A. 1976. Climate and crop productivity in Australia, p. 495-508. In: S. Yoshida (ed.). Climate and rice. Intl. Rice Res. Inst., Los Banos, Philippines.

Ortiz-Monasterio, R.J.I., S.S. Dhillon, and R.A. Fischer. 1994. Date of sowing effects on grain yield and yield components of irrigated spring wheat cultivars and relationships with radiation and temperature in Ludhiana, India. Field Crops Res. 37:169-184.

Piringer, A.A. and H.M. Cathey, 1960. Effect of photoperiod, kind of supplemental light and temperature on the growth and flowering of petunia plants. Proc. Amer. Soc. Hort. Sci. 76:649-660.

Rawson, H.M. 1988. Effects of high temperature on the development and yield of wheat and practices to reduce deleterious effects, p. 44-62. In: A.R. Klatt (ed.). Production constraints in tropical environments. Intl. Maize and Wheat Improvement Ctr. (CIMMYT), Mexico City.

Ritchie, J.T. and D.S. NeSmith. 1991. Temperature and crop development. In: J. Hanks and J.T. Ritchie (eds.). Modeling plant and soil systems. Amer. Soc. Agron., Madison, Wis.

Savin, R. and G. Slafer. 1991. Shading effects on the yield of an Argentinean wheat cultivar. J. Agr. Sci. 116:1-7.

Watts, W.R. 1972. Leaf extension in Zea mays. J. Expt. Bot. 23:713-721. 